\title{
Altered ontologies of the seascape: local knowledge, environmental change and conservation in Kihnu, Estonia
}

\author{
Joonas Plaan ${ }^{1}$ \\ Memorial University of Newfoundland, Canada \\ Tallinn University, Estonia
}

\begin{abstract}
This article explores the roots and paths of changing discourses about the natural environment and marine resources in the seascape of Kihnu, Estonia. The ontology of the seascape is never static, being subjected to constant transformation, as local experiences and understandings collide with external influences, regulations and constraints. By focusing on the indeterminacies of agency, and human encounters and environmental events, I show how Soviet pasts and perceptions, shifting scientific paradigms and practices, the dynamics of local-global articulations, and unforeseen transformation in the marine environment have progressively contributed to new understandings of the seascape, seals and other marine resources. These changing perceptions fundamentally challenge previously-held notions that humans and nature belong together. A traditional seal hunt had endured in the Baltic Sea for centuries, but the decline of the seal population in the 1970s was widely understood as anthropogenic, related to overfishing, large scale seal hunts and pollution. While most Baltic Sea coastal waters have remained closed to any type of seal hunting for more than 40 years, many fishers and marine scientists agree that grey seal population has recovered and some Baltic Sea countries have lifted the ban on hunting grey seal. While the seal hunt and meat used to have great cultural importance, there was also commercial value in seal skin and fat for many coastal communities. Several representatives of fishery-dependent coastal communities in Estonia now publicly express a view that seals now compete with fishers. Consequently the seal has lost its cultural importance and is considered as an intruder to Kihnu cultural space. I argue that making sense of the concerns and uncertainties that presently surround the question of knowing about and managing marine ecosystems, requires paying close attention to the ways in which access to the seascape and its resources have been enforced and altered over time.
\end{abstract}

Key Words: Estonia; small-scale fisheries; seascape approach; ontology; local knowledge

\section{Résumé}

Cet article explore les racines et les chemins des discours changeants sur l'environnement naturel et les ressources marines dans le paysage marin de Kihnu, en Estonie. L'ontologie du paysage marin n'est jamais statique, elle est soumise à une transformation constante, car les expériences et les conceptions locales se heurtent à des influences, des réglementations et des contraintes externes. En me concentrant sur les indéterminations de l'agence, des rencontres humaines et des événements environnementaux, je montre comment les passés et les perceptions soviétiques, les paradigmes et les pratiques scientifiques changeants, la dynamique des articulations local-global et les transformations imprévues du milieu marin ont progressivement contribué à de nouvelles compréhensions. du paysage marin, des phoques et d'autres ressources marines. Ces perceptions changeantes remettent fondamentalement en question les notions précédemment admises selon lesquelles les êtres humains et la nature vont de pair. La chasse au phoque traditionnelle a également eu lieu dans la mer Baltique pendant des siècles, mais le déclin de la population de phoques dans les années 1970 était largement considéré comme anthropique, en raison de la surpêche, de la chasse au phoque à grande échelle et de la pollution. Bien que la plupart des eaux côtières de la mer Baltique soient restées interdites à tout type de chasse au phoque pendant plus de 40 ans, de nombreux pêcheurs et spécialistes des sciences de la mer s'accordent pour dire que la population de phoques gris s'est rétablie et que certains pays de la mer Baltique ont

\footnotetext{
${ }^{1}$ Joonas Plaan, PhD Candidate, Department of Anthropology, Memorial University of Newfoundland, Canada; and Lecturer in Anthropology, Department of Anthropology, School of Humanities, Tallinn University, Estonia. Email: joonas.plaan "at" tlu.ee. I am thankful to the community members and fishers, marine scientists and environmental officials who participated in this research. I am especially thankful to Mare Mätas and Ivar Jüssi for their help and suggestions at the initial phase of the research. Thanks to Franz Krause, Tony Knight, Reade Davis, and anonymous reviewers for their thoughtful comments.
} 
levé l'interdiction de la chasse. Alors que la chasse au phoque et la viande avaient une grande importance culturelle, la peau et la graisse de phoque présentaient également une valeur commerciale pour de nombreuses communautés côtières. Plusieurs représentants de communautés côtières estoniennes dépendantes de la pêche expriment maintenant publiquement l'opinion selon laquelle les phoques sont en concurrence avec les pêcheurs. En conséquence, le phoque a perdu son importance culturelle et est considéré comme un intrus pour l'espace culturel Kihnu. Je soutiens que pour donner un sens aux préoccupations et aux incertitudes qui entourent actuellement la question de connaître et de gérer les écosystèmes marins, il faut prêter une attention particulière à la manière dont l'accès au paysage marin et à ses ressources a été renforcé et modifié au fil du temps.

Mots clés: Estonie; pêche artisanale; approche du paysage marin; ontologie; savoir local

\section{Resumen}

Este artículo explora las raíces y las rutas de los discursos cambiantes sobre el ambiente natural y los recursos marinos en el paisaje marino de Kihnu, Estonia. La ontología del paisaje marino no es estática, al estar sujeta a una transformación constante, cuando experiencias locales y entendimientos se enfrentan a influencias externas, regulaciones y restricciones. Con un enfoque en la indeterminación de la agencia, y en los encuentros humanos y eventos ambientales, muestro cómo los pasados y las percepciones soviéticas, los paradigmas y prácticas científicas cambiantes, las dinámicas de las articulaciones local-global, y las inesperadas transformaciones en el ambiente marino han contribuido progresivamente a un nuevo entendimiento del paisaje marino, las focas y otros recursos marinos. Estas percepciones cambiantes desafian fundamentalmente a nociones previas que sostienen que los humanos y la naturaleza van de la mano. Una caza de focas tradicional ha perdurado por siglos en el Mar Báltico, pero el declive de la población de focas en la década de 1970 fue ampliamente entendida como antropogénica, relacionado con la sobrepesca, caza a gran escala y la contaminación. Mientras que la mayoría de las aguas costeras bálticas han permanecido cerradas por más de 40 años a cualquier tipo de caza de focas, muchos pescadores y científicos marinos concuerdan que la población de foca gris se ha recuperado, y algunos países en el Mar Báltico han levantado la prohibición de su caza. Mientras que la caza de foca y su carne solían tener una gran importancia cultural, había también, para muchas comunidades costeras, un valor comercial su piel y grasa. Un gran número de representantes de comunidades costeras dependientes de la pesca en Estonia, han expresado públicamente su perspectiva en la cual las focas compiten con pescadores. En consecuencia, la foca ha perdido su importancia cultural y es considerada un intruso en el espacio cultural de Kihnu. Yo sostengo que haciendo sentido de las preocupaciones e incertidumbres que rodean las cuestiones de saber sobre y manejar ecosistemas marinos, requiere prestar atención a las formas en que el acceso al paisaje marino y sus recursos, se han usado y se han alterado a través del tiempo.

Palabras clave: Estonia; pesquerías a pequeña escala; aproximación de paisaje marino; ontología; conocimiento local

\section{Introduction: local knowledge, environmental change and conservation on Kihnu Island}

We had been sitting in Kihnu Island Community House for two hours listening to presentations by marine biologists, local politicians and fishery managers. High officials and politicians, scientists and managers were touring in Pärnu County, in the southwest of Estonia to present a new marine management plan for the Gulf of Riga. Graphs and map projections of the area, bureaucratic language and science were used to explain the current environmental situation and to present future plans. The aim of the 'tour' was to hear local voices and as one of the senior marine scientists later said, to include local knowledge and cultural particularities into the planning process. Nevertheless, this new inclusive approach did not necessarily represent a democratization of scientific governance, and as Levidow and Harris demonstrate. It could actually serve to promote and conceal a particular socio-political agenda (2001:357).

This was not the first time marine scientists, managers and politicians had visited Kihnu Island to present new marine conservation regulations or to talk about protected species. But as many community members had earlier expressed, so far no one has wanted to hear their voices, instead teaching them how they should (or are allowed to) live in their 'cultural space.' This is at least how locals perceived it and I could see this from the attendance of community members. Aside from the head of the municipality, his secretary and the director of the local museum, there were only two local people - a retired small-scale farmer and the fishers' representative. It was fishing season and most men were at sea while women were farming. No local people spoke until Robert 
Aps, the senior marine scientist gave a presentation about the current health of the fish population, mainly focusing on Baltic Herring [Clupea harengus membras] and European Perch [Perca fluviatilis].

Suddenly Mihkel Leas, the representative of the fishers declared, "we demand that the fishing quotas be reviewed", when he stood up in the middle of the talk. "Today the figures are wrong, which makes us criminals", he continued. This surprised the senior marine scientist, after all, a survey is conducted every year and the figures are produced scientifically. The talk of scientific evidence offended the representative of the fishers:

The scientists come here only in July, when the weather is at its warmest; they put the nets out only a few hundred meters from the shore, and after a week, they declare that there are no fish. Of course there are no fish! The fish are 5 kilometres from the shore, where the deeper and colder waters are. We go out every morning with the scientist from the same harbour and not once do they ask us where we go or where the fish are. (Mihkel Leas 2013)

The marine scientist invited everybody to come and look at the map and he asked the fisher to show him where they fish in July.

I can show them when they come here, but I won't mark it on the map. We [the Kihnu fishers] have already openly declared that as long as the rules don't change we will keep robbing the sea. (ibid)

I had heard also from other fishers how they "rob the sea" as a protest against the regulations. Several fishers stated that 'the specialists' do not know anything about the local environmental conditions, but at the same time fine them for not following the regulations, which do not reflect the reality. ${ }^{2}$ The difference between reality and scientifically produced knowledge about marine environment was constantly contested by fishers, who see the seascape around Kihnu Island as their 'cultural space', one the one hand. Marine scientists and environmental managers believe that in order to protect the fragile and unique environment around the island, it must to be scientifically managed and in some cases, isolated from human activity, on the other hand.

Focusing on Kihnu Island in southwest Estonia the article describes how environmental knowledge is created on the seascape through human-environmental encounters and various practices in the past and present. It includes the practices of Kihnu people, marine scientists and environmental officials. The seascape around Kihnu is a space where the islanders' perceptions of the environment, their identity and their livelihoods interact with conservation regulations and state power. In this context, knowledge about the sea is constantly being recreated and transformed in a process where past events, changing environments and various groups interact and shape each other, eventually altering ontologies of nature.

The article builds on prolonged ethnographic engagement among people living and working in the Gulf of Riga and the Väinameri off the western coast of mainland Estonia since 2011. More precisely it uses a particular set of cases explored during fieldwork in 2013 and 2014 on Kihnu Island. The material discussed consists of interviews, participant observation, archival research, document analysis and field trips. Fieldwork was conducted primarily on the island of Kihnu and in the four villages on the island, where I interviewed local cultural activists, municipality officials, active and retired fishers and their family members. In addition to this work, I have been interviewing environmental officers and scientists from the Environmental Board ${ }^{3}$ and the Environmental Inspectorate, working in the regional centre, the city of Pärnu and in the capital Tallinn. During my ethnographic engagement I joined marine biologists in their fieldwork studying seal migration in the Baltic Sea and I spent a fishing season fishing with two crews from Kihnu Island. A variety of insights and different

\footnotetext{
${ }^{2}$ In order to explain the conflict, Kihnu community members consistently used Estonian word tegelikkus, which means in English either reality or the real situation.

${ }^{3}$ The Environmental Board is an organisation whose task is to implement state environmental and nature conservation policies and to contribute to the development and improvement of legal acts and other official documents related to the environment. The Environmental Board falls within the area of governance of the Ministry of the Environment.
} 
experiences of working at sea gave me valuable understandings how seascape is practiced in different, but overlapping ways.

Formal environmental policy, based on science, creates resistance among the fishers, who claim that the conservation restrictions and fishery management do not conform to the real situation. "These environmental politics are a politics of knowledge" (Goldman and Turner 2011: 2, emphasis in original). They depend to a great degree on knowledge claims about the past and future changes to the sea, and on the cultural characteristics of local marine resource users and protectors. What Kihnu fishers believe and environmental scientists count as the 'real' situation in the marine environment shapes arguments and outcomes.

Studies of environmental knowledge from the last two decades have noted that lesser authority is accorded to non-scientific knowledge, and it is given a subordinate position in power relationships with outsiders, scientific knowledge holders and producers (Agrawal 1995; Dei et al. 2000; Shiva 1996; Zent 2009). There are, however, some voices cautioning that neither non-scientific, local environmental knowledge nor scientific knowledge should be taken as static and bounded (see Ellen 2002; Goldman, Nadasdy and Turner 2011). Scientific knowledge and technologies participate in the local and global social world, being shaped by it, and simultaneously shaping it (Law 2004: 12, emphasis in original) and that the so-called more powerful official knowledge is also fragile and embedded in local knowledge and vice versa (Mathews 2011). This article is a brief attempt to explore and emphasize the interactive engagement of different knowledge systems in a process of making new ways of knowing about nature, which is embedded in socio-historical contexts marked by human-human and human-environmental encounters through time and space. By focusing on the indeterminacies of agency, human encounters and environmental events, I show in what way local perceptions, the Soviet past and EU politics, shifting scientific paradigms and practices, power-laden local-global networks, and unforeseen changes in the marine environment have interlocked in a situation where new understandings about the seascape, seals and other marine resources fundamentally challenge previously held notions that Kihnu seascape is inseparable from its social world. I will elaborate the notion more in the historical overview of interactions of Kihnu people and marine environment.

The article is structured into several parts to describe the shift in the ways in which Kihnu seascape is perceived. After a short overview of the theoretical approach, I present a description of the Kihnu community and the surrounding seascape, including the present situation and historical background. The emphasis is on human-sea interactions. Focusing on a smaller island called Sangelaid and the surrounding seascape, near Kihnu Island, the bulk of the article concentrates on the practices of different agents acting in the seascape, including the sea, Kihnu people, environmental scientists and officials. In an attempt to loosen the nature-culture dualism, the sea becomes an equal agent with humans in the story. I then look closely at how different environmental officials and scientists attempting to protect the seascape have become entangled with the language of bureaucracy. I show how the practices of different agents today interact with each other, and finally how people know and manage the seascape. The article shows how different knowledge traditions, whether local, scientific or official, flow through each other over time and create new ontologies of the sea, marine resources and other non-humans living there.

\section{A seascape approach to political ecology: linking the socio-economic and political with non-human and ontological representations}

A landscape approach in political ecology studies the 'relational spaces' formed by cross-scalar social, economic, and human-environment interactions (Batterbury 2001; Huff 2014; Neumann 2011; Zimmerer 1999). This article proposes a seascape approach that extends this. Since the 1990s political ecology has been interested in the interaction between changing environment and the socio-economy. Studies using this approach have shown that the material and discursive processes and relations between landscape and resource users continuously condition context - the ways people are embedded into the landscapes through iterative practices and how landscapes are shaped simultaneously by local and extra-local socio-economic and political processes (Batterbury 2001; Huff 2014; Neumann 2011; Zimmerer 1999). These interactive contributions, the effects of different scales and hierarchies of socio-economic and political institutions (e.g. person, household, village, 
region, state, global) has been conceptualized as what Blaikie and Brookfield (1987: 17-19) called "regional political ecology."

A second, post-structural approach in political ecology examines different states of nature, their change through time and their contested representations that are affected by unequal power hierarchies (see Bryant 1998). In this view landscape is not only a type of reciprocal relation, where resource users respond to changes in the environment. Instead landscape is also that which is perceived, experienced, created, and acted upon (Huff 2014).

In one of the most recent representations, landscapes "gather topographies, geologies, plants and animals, persons and their biographies, social and political relationships, material things and monuments, dreams and emotions, discourses and representations" (Tilley and Cameron-Daum 2017: 20). Landscapes and the physical processes affecting them, are seen as historically constructed and in continuous relationships with resource users and the socio-economic and political sets of relations which shape both landscapes and their inhabitants (Blaikie 1999: 132). Many landscape studies focus on the daily lives of social actors, on "everyday experience" (Rose 2002: 457), on "processual daily practices" (Gareth and Metzo 2008: 224), and on 'mundane activities and struggles' (Scott 2006: 493).

Taken all this into consideration I will try to move beyond landscape into seascape. The term seascape is commonly used to refer to visual representation of the sea, the coast or ships (McNiven 2008). I suggest that we should consider seascape not only as a visual representation. Rather, drawing on how Blaikie (1999) and many others have considered, I suggest we can approach it as the reciprocal relations of social agents and the environment. Seascape, like landscape, is "contoured, alive, rich in ecological diversity and in cosmological and religious significance and ambiguity..." giving us a new perspective how people living and working there "actively create their identities, sense of place and histories" (Cooney 2003: 323). Seascape includes the nonhuman, and is made up of embodied and lived experiences, representations and perceptions of being in and on the sea, and of the historical and social dimensions that constitute individual and collective understandings of the sea (Brown 2015). Hence, seascape and landscape have many similar characteristics, but there are two distinctive qualities to note about the seascape.

One contrast with landscape, is the fluid and ever-changing nature of seascape. Strang notes that the "most constant "quality" of water is that it is not constant" (2004: 49). It is the very notion of the fluid, moving and changing nature of the sea that opens up the space to consider it as a seascape, something that shapes us both through physical processes and social interactions (Steinberg 1999). Moreover, recognizing this fluid nature is also to draw attention to the fact that seas cannot be fully controlled, in the way a bounded territory on land can be physically controlled, and so the seascape must be treated as active rather than passive. At the same time, the sea's liquid and fluid nature has often seen as problematic, and it has led to "categorical difficulty and ontological uncertainty" (Connery 1996). These different perceptions, values and knowledges, often lead to contested debates about what sea is (ontology) and how do we know it (epistemology).

Secondly by contrast, compared to landscape, is the fact that little is known about ecological and biophysical processes in the seascape, and it is often the case that these environmental dimensions reveal themselves only years later, if at all. Perhaps it is because human activity does not leave permanent visual marks on a seascape as happens with a landscape (e.g. agriculture), it has long stayed on the edge of academic inquiry or has been represented as something exterior to it. Consequently, our knowledge about the ecological and biophysical dimensions of seascape is considerably poorer than our understanding of these dimensions of landscapes. Despite the long history of environmental studies of the Baltic Sea, little is known about the fish stocks and biophysical conditions, and there are knowledge gaps relating to the sea floor as well as major threats to the Baltic (Kraufelin et al. 2016). These unknowns of the seascape make way for contestation over knowledge. In these debates, the knowledge there is, is never objective. Rather, it becomes part of "a sociocultural process produced through particular relations of power", in which some natures, knowledges and people are valued above others (Burke and Heynen 2014: 8).

The seascape approach emphasizes the fluid and ever-changing nature of the sea, and second, it considers the unknown aspects of its ecology and biophysical processes. I argue that a seascape is a relational space of sea and land, marked by variety of possible relationships between people, ecological environment, materials 
and geographies. These relationships are based on an interactive process where a seascape is perceived in culturally specific ways (Lambert et al. 2006; Torrence 2002) filled with symbolic meanings (Brown 2015).

Nevertheless, as I studied more closely the various ways in which people interact with and speak of the seascape, I realized that there may be multiple understandings of what is seascape. Leaning on Mol's (2002) study I learned how the practices of fishers, marine scientists, fisheries inspectors and environmental officials enact multiple, but overlapping, versions of seascape. This suggest that there are perhaps multiple ontologies of seascape: its theories of being and reality. In other words, is there one "real" world or does it depend upon the point of view of the observer? Multiple realities do not mean that there are determinate set of discoverable entities on the same object (Law 2004). Instead ontologies are blurry and come into existence only in specific circumstances, an example being Amerindian perspectivism (Vivieros de Castro 1998), Yukaghir hunters' animism (Willerslev 2007) or relational mountain beings in the Andes (Stensrud 2018), where non-humans come alive through relations with humans. In those moments multiple ontologies coexist, creating "a space" open to potential new worlds and transforming old ones (Rubow 2013: 61) but also creating potential ontological conflicts (Blaser 2013). What is then happening is that "different realities are being constantly created and mutually adjusted so they can be related, and realities depend upon their continued crafting and enactment - in a combination of people, things, techniques and natural phenomena" (Stensrud 2014: 80). Ontologies, then, are never static, being subjected to constant transformation.

Diverse and entangled realities are born through different practices - including knowledge practices and material practices (Stensrud 2014: 78). Conservation policies, fisheries regulations and local ways to manage the environment makes seascape a highly controversial and politicized space in Kihnu. The seascape is practiced in multiple, but overlapping ways, depending how different social groups understand the sea. It can be both countable units of tonnes of fish or numbers of protected species, separated from human activity, but also a intangible source of social formation and inspiration for cultural life.

Interactions between different ontologies, understandings of what is seascape? in this case, show that they are not just descriptive models of the world, but also models for action (Reuter 2010: 9). The practices of different groups are directly guided by those understandings. For example, whether a certain bird species is considered as a family member or, on the contrary as a threatened species that needs protection, becomes a model for the interaction with that species. As different social groups and different ontologies encounter each other, how they know their reality will be contested, transformed and in some cases, new knowledge will be created. The transformation occurs when everyday activities are practiced, making factual knowledge important, but also situated knowledge on how to do something (Ingold 1993). Overall, I propose that the liquid and fluid nature of water also characterizes knowledge about the seascape. I have two aims. First, I suggest that ontologies are never simply 'out there' to be experienced and understood by different social groups, even by anthropologists, but are embedded with local environmental knowledge, that is, again, not just discovered or invented but created through social interactions and human encounters in the past and at the present. Second, I show how local knowledge is woven into diachronic and contemporary discussions and practices about conservation, protecting endangered species and controlling fisheries.

\section{Kihnu cultural space: where people, land and sea meet}

Kihnu is a small island $10 \mathrm{~km}$ off the southwestern coast of Estonia (Figure 1). Kihnu Island, the neighbouring Manija Island, 56 uninhabited islets and the surrounding seascape comprise an area called the Kihnu cultural space ${ }^{4}$, listed by UNESCO as Intangible Cultural Heritage. It is a diverse environment where great biodiversity encounters a social setting with rich cultural activities, most importantly small-scale fishing, collecting bird eggs and hunting seals. Nevertheless, according to EU policy, most of the area is under environmental protection as a unique ecosystem in Estonia and more widely in Europe. This makes some

\footnotetext{
${ }^{4}$ Kihnu Cultural Space is a label created by Kihnu cultural activists and supported by UNESCO in the late 1990s when they applied to be included on UNESCO's list called Masterpieces of Oral and Intangible Heritage of Humanity. It is a term of objectified culture, which has been formulated using precise criteria, where culture is defined as cultural artefacts, rather culture itself (see Plaan 2012). Nevertheless, Kihnu cultural space (Kihnu kultuuriruum) is also a term used most commonly by locals when they describe the area they call home, comprising Kihnu Island and the surrounding seascape.
} 
cultural activities, like egg collecting and seal hunting, illegal. At the same time, the space has been used by the Kihnu community for centuries. Consequently, even today, as I was doing my fieldwork on the island in 20132014, residents call the island and surrounding sea their backyard ${ }^{5}$ where they are used to getting important resources for their livelihood.

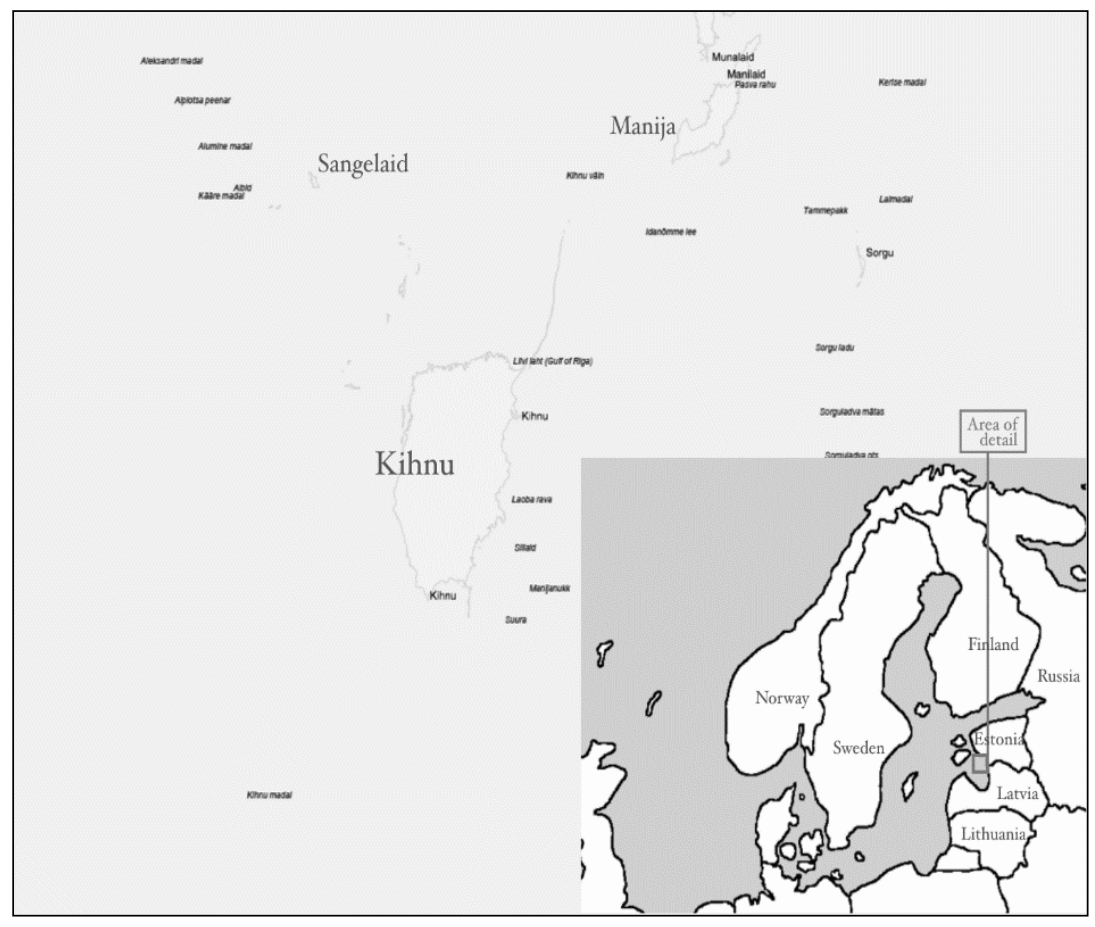

Figure 1. Map of the Kihnu cultural space, Kihnu Island, and Sangelaid Islet. Adapted by the author from maps by Maaamet.

Given the recognition of place and heritage, it is hard to undervalue the influence of the sea, sea routes and resources. By the turn of the 20th century Kihnu had been inhabited for at least 400 years. Today, about 600 people live on the island. Marine resources and knowledge about the sea have connected the community to the rest of the world, saved the islanders from oppressors, and always played a major role in Kihnu's economy and its identity (Kalits 2006; Rüütel 2013). In the late 19th and early 20th century, Kihnu seafarers were regular visitors to most ports in the Baltic Sea and beyond, trading seal fat and skins, and selling stones for construction that they had collected from the sea surrounding Kihnu. Women, on the other hand, made long trips to the mainland in winter to sell salted herring from the autumn catch. As the resources of the sea were exported to neighbors, the men and the women returned with diverse cultural influences. For example, new seal hunt techniques were imported from the Finnish coast and women's traditional clothing became more colourful once men started to bring dyed cloth from London, UK in the late 19th century. Many young women stayed on the mainland for the summer working as maids, returning with new cultural habits and customs. Overall, the Kihnu community has always been more connected to the sea than to the land.

The sea has not only connected but also kept islanders protected from oppressors, and they lived in a certain isolation compared to the mainlanders. The power of the state has not always extended to the island. In 1887, the Kihnu community was emancipated from feudal landlords, who had governed the area since the 16th century, and the land was distributed to the islanders (Kalits 2006: 17). This event was unique in Estonia at that

\footnotetext{
${ }^{5}$ There is no word for nature in Kihnu dialect and to describe the natural environment they use either the word õu (backyard) or vällas (outside).
} 
time. On the mainland the peasantry usually worked under landed classes. Life in Kihnu was much freer than in other parts of Estonia and the island community felt self-reliant and independent (Jõgisalu 2006; Kalits 2006; Peil 1999). It is a characteristic that still plays an important role in Kihnu identity. This was reinforced during the Soviet Era (1944-1991). The former debts of the fishers were cancelled and the entire fleet was motorized, new fishing techniques were introduced and the sale of fish was reorganised (Rüütel 2013: 32). More than that, during the 1940s all coastal communities in Estonia, expect Kihnu, escaped to the West or were forced to resettle on the mainland. Locals and mainlanders remember life in Kihnu as having been much better than elsewhere in Estonia during the Soviet era.

The practices in the past, relations with others, and different perceptions and usages of the sea dictate human-environmental interactions in the Kihnu cultural space today. Above all, knowledge about the sea and how to manage it is conditioned by the local ecosystem and cultural conditions. The seascape around Kihnu Island has been a source of social formation and inspiration for cultural life but also a place where knowledge is created. At the same time, the sea is also a place where islander identity and livelihoods are continuously influenced by the discourse of conservation regulations and state power. The Soviet past and perceptions, shifting scientific paradigms and practices have played a role in creating new understandings of the Kihnu seascape. The next section shows how local environmental knowledge in the Kihnu cultural space is created, transformed and transmitted through practices at sea, with individual encounters and interactions between different actors in the seascape.

\section{Knowledge circulation and altered ontologies}

In order to explain knowledge creation and ontological transformation alongside environmental processes, I will focus on human-environment interaction on Sangelaid Islet and the seascape surrounding it (Figure 1). Sangelaid Islet and the protected area created around it is part of the Kihnu Protected Area. The area is the greatest source of conflict between the locals and state conservationists at present. On the one hand, the Kihnu people claim it is their cultural area; on the other hand, the conservationists see it as nature reserve with great biodiversity. What is the reason for such different perceptions and why do they create conflict between different sides? Also, what kind of role has knowledge about the environment and practice played here? How does this alter ontologies of the seascape? These are the questions that the rest of the article tries to answer.

\section{The land that rises from the sea}

In the process of creating knowledge about the seascape, nature plays a major role. The seascape in the Kihnu cultural space is in constant transformation. We can find several examples of this, like geological processes. Kihnu Island rose out of the post-littorina Baltic Sea about 2,000 to 3,000 years ago (as human societies transitioned from the Neolithic to the Bronze Age in this region; Ratas 2005). Today the land rises about $2.5 \mathrm{~mm}$ annually in this part of Estonia (Vallner, Sildvee and Torim 1988). Uplifts creates, transforms and destroys fishing grounds. Moreover, uplift affects how currents move and waves erode the surface. Even more, there are changes in water temperature and salinity (Speek 2008: 32). Overall islands coastline, shoals, reefs and habitat of the Kihnu seascape are in constant movement and over time: humans have interacted with a changing seascape.

Maps from different eras illustrate this point. On maps from 1866 to 1896, we can see that Sangelaid was comprised of two smaller islands, and did not resemble the current one (EAA 1866-1896; Figure 2). As the environment keeps shaping the seascape, it also changes human practices. Nevertheless, the changes have twoway effects. Peoples' practices may also cause changes in the environment and vice versa, though not always in a balanced way. Thus, we can think of nature's agency only in the context of human-environment interactions (Taylor 2011) and as we will see below, there have always been interactions. 


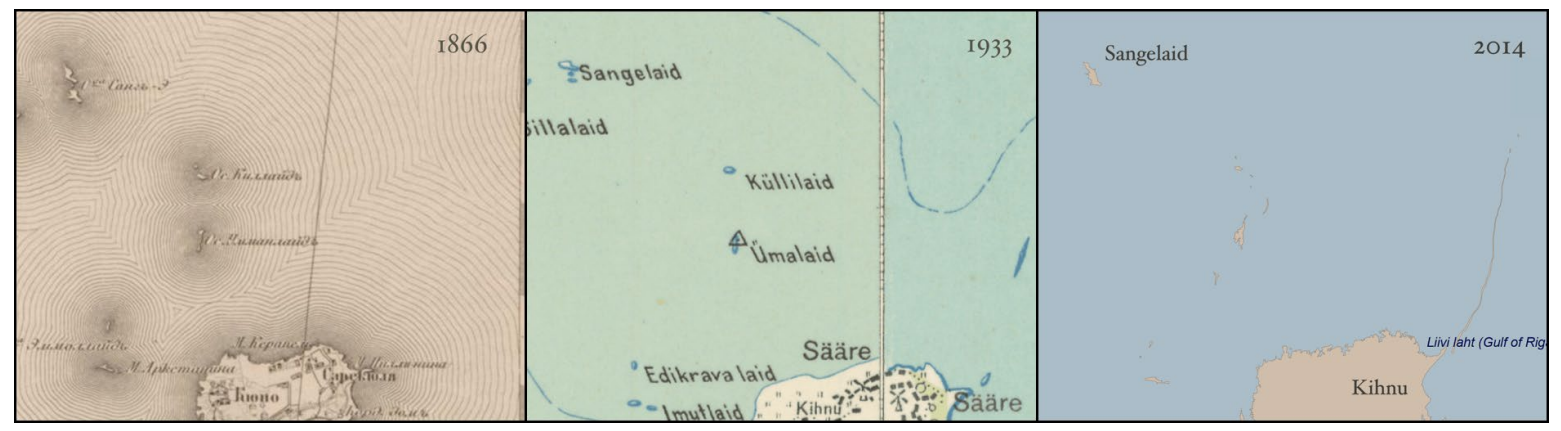

Figure 2: Changing seascape around Kihnu Island and Sangelaid Islet, 1866, 1933 and 2014.

Source: Eesti Ajalooarhiiv 1866-1896; Maaamet.

\section{First encounters}

The interaction between Kihnu people, Sangelaid Islet and the seascape surrounding it has a long history. There are records dating back to the 1800s of men from Kihnu living on the small offshore islands during the summer (EAA: 1800), and according to locals they only stopped visiting the islands because of regulations introduced in the 1990s. My host in Kihnu, a women in her seventies, described how her father used to spend all his summers on Sangelaid. They lived in small huts together with the diverse bird species on the land and the seals in the sea. They not only fished the surrounding seas, but they also hosted other fishers during stormy weather, and took care of the islands by cutting down straw and protecting nesting birds from birds of prey. In late winter Sangelaid was used as a place for seal hunting and in spring as one of the islands for collecting birds' eggs. Older islanders recall that in the spring, the children collected seagull eggs and destroyed crows' nests on the islets surrounding Kihnu. Men who do this today believe that it helps to balance the population of birds. As I was collecting stories of Kihnu people and bird interactions, I was told that crows were seen as mainland intruders and islanders tried to kill as many as possible, then later, seagulls were considered birds of prey. To limit their population, islanders usually removed two or three of their eggs. Although this is illegal today, some fishers still keep the practice alive, as I witnessed on several fishing trips during my fieldwork. The eggs were used to make pastry later or eaten boiled on fishing trips. Men had observed that otherwise there would be too many seagulls who would scavenge other bird nests, or as Jõgisalu (2006) observed, some fishers considered certain species ${ }^{6}$ as part of their family. In addition, the islets were used for navigation for those who were coming and going in a westerly direction. Thus the fishers passed the small islets constantly and were familiar with the local environmental conditions. In this process the 'sea of islands' around Sangelaid became part of Kihnu cultural space, Kihnu people's back yard.

In Kihnu's cultural space, the islanders have used the environment and its resources for centuries, also creating habitats for a great variety of species. Contemporary environmental officials, however, believe that the seascape must be protected from humans: "In our eyes [The Environmental Board] people and nature do not belong together." (Interview with Nele Saluveer, Director of The Environmental Board). As a result, most of the Kihnu seascape is now protected as a pristine ecosystem with great biodiversity (see The Environmental Board 2012). In spite the fact that extensive research has shown globally that biodiversity is created and maintained by people who live within it (Redford et al. 2006).

In this situation, the encounters between different perceptions of the seascape create not only conflicts but also new types of knowledge. One reason for such different perceptions is the past isolation of the Kihnu community. While Kihnu people managed to travel relatively easily, particularly during the Soviet era,

\footnotetext{
${ }^{6}$ Harri Jõgisalu (2006) describes how some fishers consider common merganser (Mergus merganser) and red-breasted merganser (Mergus serrator) as part of their family.
} 
mainlanders needed special permission to visit the island and some other localities in the region. Consequently, conservation biologists and environmental officials were unfamiliar with the island and its cultural practices. Nevertheless, old diaries and personal memoirs provide examples of how insights emerged from scant encounters.

The first recorded encounters between islanders and natural scientists in Kihnu cultural space occurred during the Soviet era. The few natural scientists who had the opportunity to visit felt affection for the pristine nature and this prompted the establishment of conservation measures. This became clear as I went through archival material and old scientific memoirs from the period. In the late 1950s, Harri Jõgisalu, a nature writer and photographer travelling with mainland fishers, accidentally landed on Sangelaid Islet during a storm. The day after the storm he "discovered a seabird heaven" (Jõgisalu 2006: 23). Later back in Tallinn he showed pictures of Sangelaid to his biologist friend. The following year, Jõgisalu and his friend visited the island to count and ring birds. Sangevana, an old fisherman who lived on Sangelaid during the summers, helped them with the job. He knew every nest and bird on the island, often treating them as domesticated animals ${ }^{7}$ (ibid: 40). Afterwards Sangelaid became famous as a bird haven in conservation circles and many expeditions followed.

Soon the local knowledge possessed by Sangevana and other men that preceded and followed him was transformed into scientific knowledge, which was used to create the first protected area in Kihnu cultural space. Of course the process was not as smooth as I present here but the main point is that as Sangevana showed various island birds to the naturalists ${ }^{8}$, then the species were not only scientifically classified but also assessed according to their rarity in national terms. Certain aspects of nature got "packaged and categorised", which set them into the circulation of scientific knowledge systems (Turner 2011: 28-29). Following from this, thanks to Jõgisalu's "discovery", in 1964 Sangelaid Islet was put under protection as an area with great biodiversity and "pristine nature" (Pärnu raj. TSN TK resolution no. 26, 1964). Crucially, data collected in the late 1950s and early 1960s established a conservation benchmark for normal habitat to be maintained in the future.

Today people are not allowed on the small islands during spring and they claim that the 'specialists' from the Environmental Board are not doing their job. The islands have become overgrown, the cormorants have taken over and foxes are eating the bird eggs. Therefore, the biodiversity that had earlier been protected and is considered unique and normal in conservation circles, no longer exists. Moreover, the fishers do not have a place to rest for the nights when they are at sea. The people in Kihnu feel that conservationists have taken their land ${ }^{9}$ and ruined it. This has happened in the process of conserving the normal and making it pristine.

\section{The language of bureaucracy}

In order to understand why conservation officials perceive Sangelaid and its surrounding seascape as pristine we have to look at the roots of different conservation actions. Today Sangelaid Islet is among eight smaller islands that are located northwest of Kihnu and are part of the Kihnu Protected Area. Compared to most other protection areas in Estonia, it is one of the most restrictive areas for human activity. Sangelaid Islet and the seascape surrounding it is protected by eight different conservation measures (Figure 3). ${ }^{10}$ There are two

\footnotetext{
${ }^{7}$ Sangevana was constantly checking bird nests and if needed softened them with seaweed or if the mother bird had been away too long, covered the eggs to keep them warm and hidden from birds of prey.

${ }^{8}$ Conservation biology as we know it today was not given legal status in the Estonian Soviet Socialist Republic until 1957. Environmental protection had no legal, political or financial support. Thus, people who visited Sangelaid in the late 1950s were either conservation biologists before the occupation started in 1944, hobby ornithologists or scientists from other fields. Most of them became conservation officials or scientists at a later date.

${ }^{9}$ In conversations, Kihnu people use the words land and sea interchangeably when they talk about the seascape in the Kihnu cultural area.

${ }^{10}$ Next to the Kihnu Protected Area there is Sangelaid Protected Area with unrevised protection rules, Sangelaid Baltic Sea Ringed Seal Protection Site, Sangelaid Baltic Sea Ringed Seal Protection Site Conservation Zone, Sangelaid Baltic Sea Ringed Seal Protection Site Limited Management Zone, the Pärnu Bay Special Protected Area, the Kihnu Special Area of Conservation, and finally Pärnu Bay Limited-conservation area.
} 
reasons for this: through time different groups of environmentalists have managed to enforce new restrictions, and secondly, because of political changes in Estonia.

The first conservation measures were initiated by ornithologists who visited Sangelaid in the 1950s, as detailed above. In the 1970s measures were added to protect the ringed seals that bred there annually, as marine biologist Ivar Jüssi recalled during an interview. At the same time conservation biologists started to demand protection for the islands' semi-natural communities (Jüssi, I., interview 2012). ${ }^{11}$ Describing the islands as seminatural lets us believe that in the 1970s the human influence was still appreciated by conservation biologists. Nonetheless, the aim of those early measures was to protect the normal seascape, which was later benchmarked in 1964. Further measures were introduced to conserve the situation recorded in the expeditions of the late 1950s and early 1960s.

After Estonia had gained its independence in 1991, in 1994 the regulations were reformed and new ones introduced. For the first time in over thirty years, Estonia had a new nature conservation law. 'Semi-natural community' as a conservation concept lost its legal force and Sangelaid Protected Area was created. Consequently, 'semi-natural community' was replaced with a new concept, 'protected area.' It is important to notice here that Estonian nature conservation law says that 'protected area' means no human activity compared to a semi-natural community, which accepts moderate human activity. Finally in the context of the enlargement of the EU in 2004, new lines were drawn and a Natura 2000 zone was created. Estonia was in hurry to be part of the EU and several environmental officials and biologists who were involved with the process recall that the zone was designated in haste. No new studies were conducted and in many cases a simple ruler was used to draw new borders. The process started with the need to protect the normal situation in the Sangelaid ecosystem but again excluding humans and their positive influence on biodiversity management.

Slowly the seascape got entangled in the language of bureaucracy. Regulations have distanced Kihnu people from the seascape around Sangelaid. Many regulations overlap, some are outdated and are waiting to be amended by officials, and others need further study. Other regulations prohibit fishing with nets or weir nets, collecting sea eggs and hunting seals (Ministry of the Environment 2011). As a result of the latest amendments no one is allowed in the area between February $15^{\text {th }}$ and November $14^{\text {th }}$. It is not only Kihnu residents that find the regulations hard to follow. Environmental officials have also puzzled. When I asked Nele Saluveer, the head of the Environmental Board if she understands which measures affect Sangelaid Islet, she admitted diffidently:

Yes, the bureaucracy is beyond me. It is hard to understand everything ... I imagine that for a person that is not used to it, all the databases and systems and legal aspects, make it hard for them to understand all the regulations.

Yet the Environmental Board is the institution that manages the protected area. If a high official in the institution finds it difficult to understand the restrictions, it is even more difficult for the people who live close to the protected area and who are used to treating it as their back yard. In this process, Sangelaid has become a reality that exists only on official documents and biological surveys.

\footnotetext{
${ }^{11}$ In the interview Jüssi referred to the term semi-natural community (pool-looduslik kooslus). It is a term used to describe landscape, which has been shaped by moderate human activity.
} 


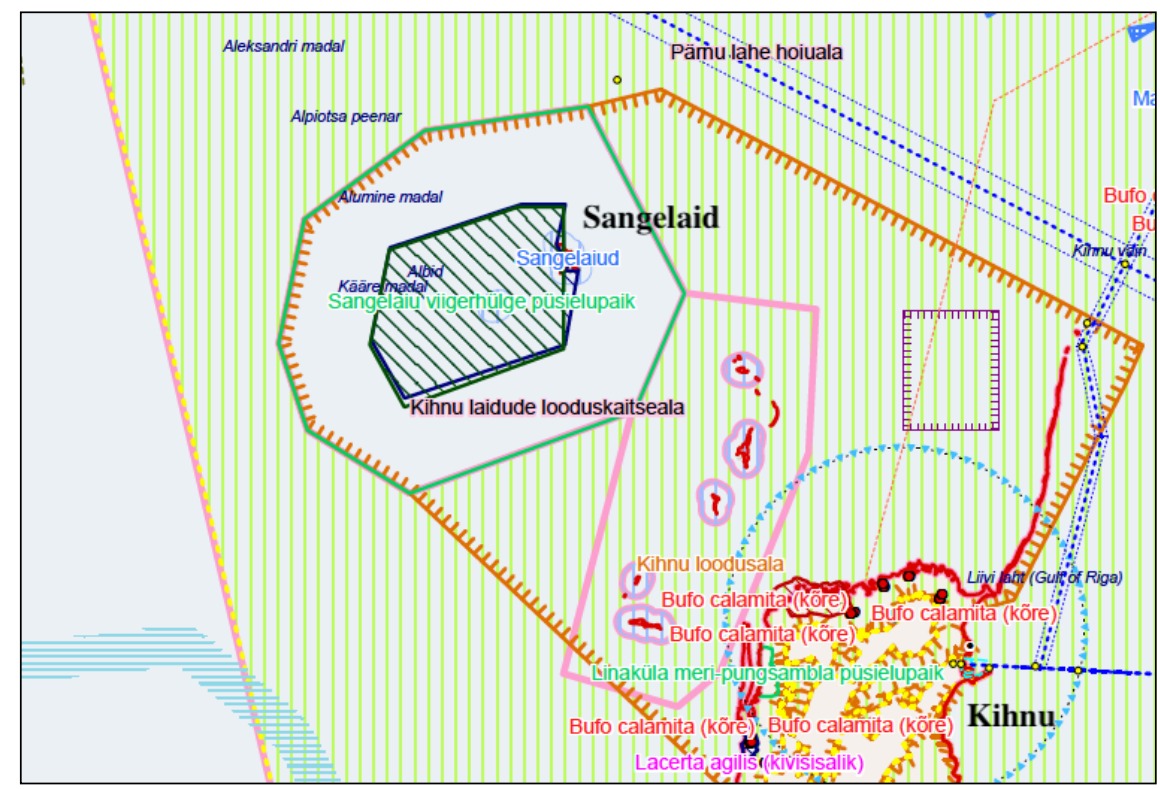

Figure 3: Sangelaid Islets and eight different conservation measures that include the islets and the seascape. Source: Kartau 2013.

\section{Seal as a predator}

In the same time, conservation measures have also created new walls between Kihnu people and grey seals, which has led to a situation where seals are no longer considered as part of Kihnu culture but as pests predators who eat fisher's income. This development has roots in the Soviet past and perceptions of nature. Between 1953 and 1972 fisheries were glorified throughout the Soviet Union and fisheries managers were encouraged to raise fish catch numbers by any means (Jõgisalu 2006: 157). With the support of pseudoscientists, fisheries managers found a reason to encourage hunting of as many seals as possible. The rational was clear-cut - seals eat fish, hence they are a problem. The quantification of seal and fish populations was manipulated, as occurred elsewhere in the world (see Bavington 2010; Hutchings 1999; Johnsen, Grant and Neis 2009). Fisheries scientists and managers in the Soviet Union believed they could control and manipulate nature as they wanted. Soviet fisheries scientists also believed that natural resources are there to be taken. For example, Trofim Lysenko, a leading marine biologist and agronomist in the Russian Academy of Science, kept praising large catches without concern about the fish population (Jõgisalu 2006: 157 cit. Lysenko). Soviet era guidebooks quoted him: "Waiting for any handouts from nature is not allowed, our duty is to take it" (Lysenko 1948).

As part of the project of controlling nature, approximately 20,000 ringed seals and 10,000 grey seals were hunted annually in the Baltic Sea in the 1960s (Harkonen et al. 2005; Reeves 1998). The seal hunt became a well-planned massacre. How many of them were killed in Kihnu or the surrounding seascape is hard to estimate but Kihnu fishers, well known as traditional seal hunters, definitely had an important role to play in those massacres. An old fisher in Kihnu recalled during an interview that they were sent all around Estonia to kill seals. So many, that he had nightmares for a long time after this (Anonymous interview, April 2013).

In 1972 grey seals were almost extinct in the Baltic Sea and the Soviet Union agreed to ban grey seal hunting in the Baltic territories as part of the Gdansk Convention (1973). The Baltic ringed seal hunt was banned in 1980 following continued hunting and pollution problems (Jüssi, Jüssi and Müür 2004). The Helsinki Commission banned the hunting of grey seals and ringed seals in the entire Baltic Sea in 1988 (Helcom 1993; 2008).

Today many marine biologists agree that the grey seal population has recovered. Consequently, many Baltic Sea countries, including Finland and Sweden, and since January 2015 Estonia, have allowed the 
traditional seal hunt. New regulations allow Kihnu men to continue their seal hunt traditions only if they do it in the traditional way and formally register their catch. Historically, the seal hunt was practiced in winter, when the sea was under ice and men used special gear and their local knowledge of ice conditions. Today, the legislation says that the 'traditional hunt' has to be done between the end of April and December. The period has been set to avoid killing any baby seals or disturbing nesting birds. Ironically, this is also the period when there is no sea ice, and it is a time when Kihnu men are otherwise occupied with fishing. So the Kihnu people cursed marine biologists openly for years for their so-called "gift", in the media and in public meetings. They demanded that the traditional seal hunt be re-established.

Years of dispute about seal hunt had created mistrust and in some cases even hatred between marine biologists and fishers. The latter blame the biologists for protecting the animal that eats their income. When I was doing fieldwork, marine biologists who were responsible for drafting the protection and hunt regulations asked me to find out how Kihnu men would like to hunt seals in the future. Almost all men thought that the best way would be to do it traditionally - on ice, with a rifle - as they did it in the 1950s and 1960s. The new regulations do not allow this. Seal hunting is officially allowed but in practice it has become very difficult.

Hence, in Kihnu, the traditional seal hunt has become an unregulated hunt for pests. Seals are no longer seen as part of Kihnu society, but are viewed as intruders in Kihnu cultural space. During my fieldwork in 2014, 40 years after the gray seal hunting ban which was still in force, many men took a rifle when out fishing. Several times I heard stories of seals eating straight from fishing nets and I was asked to document the holes they made. Seals encountered on those fishing trips were killed as predators.

\section{Entangled practices}

Today conservation measurements and resisting them have become important social practices in humanenvironmental interactions in the seascape. Resistance becomes part of the process of knowledge making. Environmental knowledge is transformed through social interactions and practices that involve groups of actors both at sea and on land. The transformation occurs when everyday activities are practiced, creating situated knowledge. Factual knowledge originates in scientific practice by the environmental scientists and officials, who assess the seascape and how to preserve it. Situated knowledge is produced empirically by people who are in daily interaction with the environment and also claim to know how to manage and use its resources. Despite the fact both consider the normal situation of the seascape, they define this differently. Nevertheless, in the process of social and environmental interactions both forms of knowledge are simultaneously factual and situated. The empirical and the scientific blur together into hybrid knowledge. To understand this complexity we have to observe how the process of knowledge-making is practiced.

One evening I went to sea with a group of men to put out some nets. Initially it felt like business as usual, but in fact we headed straight to the Sangelaid Protected Area. "Today we are going to rob the sea", one of my informants explained in an ironic tone. I had heard also from other fishers how they 'rob the sea' as a protest against the regulations, but I was very surprised when we came upon three other boats robbing the sea in the same area. It was only when we got to the protected area that I understood what they meant by robbery. I had often heard it expressed that by legally prohibiting traditional Kihnu practices in the name of environmental protection, environmentalists had taken away their land. Thus, in order to collect and catch resources from the area, to which the men felt they were historically entitled, they had to become criminals. They had to rob the $s e a$, as men described their socio-economic situation.

On earlier boat trips, I had noticed the men becoming suspicious on seeing other boats approaching, since you could never know if it might be the inspector's boat. That day the men were calm, like the sea on a calm day. When I showed my surprise at this behavior, the men laughed and explained that the inspectors were doing a raid today, but on the other side of the Bay of Riga. Enn Keeman, who was the head of the inspectorate at that time admitted in a later interview that he is knowledgeable about such illegal activities: "The biggest percentage of violations in my region comes around Kihnu Island...I can not just go and fine all Kihnu people." He described how two Kihnu women in their 80s got caught ice fishing illegally. In such cases the inspectors usually close their eyes and let Kihnu people rob the sea. 
Knowledge about the sea is not only about knowing where the fish are, or the good fishing grounds, but also about what other actors are doing at sea. The fishers' world is very complex, and their knowledge about fishing and fish is hard to separate from their knowledge about the market, regulations, and other activities (Knudsen 2009: 79). Those knowledges are constantly interacting with each other and affect not only what is known but also the ontologies of seascape. In a situation where different knowledge systems are articulated, power relations emerge.

Some knowledge systems are more hegemonic, others subordinate, or resistant. Some authors argue that official knowledge represses alternative or local knowledge (Scott 1998). Scott argues that administrative ordering of nature is done with the help of the scientific understanding of the environment and both are key elements for repression of local knowledge. Conversely, most communities select and incorporate hegemonic knowledge into their local knowledge systems, while recreating and transforming themselves through it (Escobar 1998; Gupta 1998). While the state policies have more impact than the decision of a Kihnu fisher, it does not mean that state policies always suppress fishers' decisions. State power and official knowledge do not silence the opposition or other forms of knowledge, but in many cases, the official knowledge embeds them into the local context. Knudsen noted that there is always a certain amount of knowledge sharing between agents at sea (2009: 238), and the sea is the place where the sharing occurs. We have to look at how scientific knowledge and the official knowledge it informs, is created.

\section{Knowing and managing the 'normal'}

Conservation regulations and management plans are based on science. Through scientific practices, the scientists become "familiar with things, people and events, which are distant" (Latour 1987: 220). Once a year ornithologists conduct surveys on the islands to count the bird population. Conservation biologists have to do their survey every third year and assess plant diversity. Marine biologists try to count seals every year and give their suggestions for future protection plans every fifth year. ${ }^{12}$ Ichthyologists combine their knowledge from three sets of data: from the fishing diaries that all fishers have to keep, from an annual survey based on fishers' descriptions and from an annual catch survey. The scientific knowledge about the seascape and its management is created by combining these three sets of data. Interestingly, these data sets miss out any socio-economic and cultural data. When it comes to the conservation measurements, the human is not part of the environment.

The bird and seal population survey, the plant diversity, and the fishing diary, questionnaire and catch survey should produce data that is scientifically correct, but bureaucratic realities, its isolation from Kihnu peoples' practices, and belief in normal 'pristine' nature has created a fragile knowledge base which is contested by the Kihnu community. While the aim of science is 'to be familiar with things which are distant', this is not the case for fishers. For them, what is important to know about is the here and now. For the environmental scientists the data they collect is about an environment which they visit rarely, and it is compared with data which is considered normal. The normal that was set in the 1960s. Thus, the seascape becomes spatially and temporally distant from the contemporary knowledge of local people, and their understandings of the present, place, projections and populations. Scientists and officials find it hard to include local knowledge about the environment, since it is difficult to package and categorize.

At the same time, despite the restrictions, some men keep shaping the seascape. For example, every spring, when the ornithologists have left the area, local men try to organize a hunting group to kill the foxes on the small islands. Since 2009, several men have been raiding the cormorant nests. The annual cormorant survey also shows that while the cormorant population has been increasing in the rest of Estonia, it is decreasing in Kihnu cultural space (Rattiste and Saks 2010). The authors of the survey do recognize that it is to do with the activity of Kihnu men. Some conservation biologists consider this a good thing because cormorants destroy biodiversity, but others believe that any such manipulation is disturbing 'natural' ecosystem processes. Men who are responsible for this "illegal conservation", as many environmental officials name it, claim that they are doing good for the seascape. Furthermore, they argue that if the state declares that its data shows protection is

\footnotetext{
12 Those are demands of Estonian Nature Law. However, the last assessment of plant diversity comes from 1999 and marine biologists' methods do not allow more precise findings (mostly because of the weather).
} 
effective, the conservationists' practices do not show that. For example, Kihnu men, who organised several fox culling trips to the islands, recall that in years when they did not kill foxes, there were no birds. Cormorants, on the other hand, are not only intruders similar to crows but all fishers believe them to be competitors. Although scientists agree with fishers on this point, cormorants, who used to be rare birds in Estonia in the early 1990s, are still protected (Vetemaa et al. 2010). During interviews many conservation biologists admitted that the regulations need to be amended. Overall, Kihnu people like to bring up both of those examples to illustrate that environmental scientists and officials do not know how to manage the seascape.

As in the example above showed, Kihnu people doubt the knowledge environmental scientists and officials have. The literature also shows that holders of different forms of knowledge try to suppress and question the authority of rivalling forms of knowledge and its holders (Bowker and Star 1999). Mathews shows that state power and official knowledge are an 'uncertain authority', concerned about the best ways to translate regulations, scientific knowledge, and national policies into the local context (Mathews 2011). During my fieldwork I met environmental officials who were worried if they understood the new regulations thoroughly enough, marine biologists who did not know how to include social aspects, and fishery inspectors who deliberately ignored the law because they were afraid of the social consequences of enforcement. Thus, even if there is a more powerful knowledge system, it does not suppress all local knowledge. Scientific, official and local knowledge intermingle in local practices, making it difficult to distinguish the different knowledge systems in the Kihnu seascape.

\section{Conclusion}

The proposed seascape approach has allowed consideration of the fluid and ever-changing nature of the sea, and the unknown aspects of its ecology and biophysical processes. I have studied how ontologies of the seascape in Kihnu Island have altered over last 70 years. This has shown that Kihnu fishers' ontologies of the seascape are not a product of a dominant ideology, but a product of less institutionalized and organized, more general and everyday forms of power. They are shaped by the changing marine ecosystem and by what is considered normal in the seascape. This makes knowledge about the seascape, both local and scientific, a fragile outcome of the negotiations between state officials, scientists and local inhabitants. The fishers and the officials ignore regulations as long as higher state officials believe they are being fulfilled. The scientists ignore the social situation and cultural particularities; the fishers ignore the regulations and "rob the sea"; and the officials struggle to make sense of the seascape.

Thus, the seascape and the seals that inhabit it have become spatially and temporally distant from the fishers' social and cultural world, altering their ontologies. Seals, Kihnu people, their cultural practices, and the way the sea is managed are separated from each other. The reasons for this date back to when the marine environment altered, and knowledge about it became packaged and categorized. Altered fishing grounds, the Soviet past and the perceptions of that period, and shifting scientific paradigms and practices have all played a role in this separation. As I have tried to show in this article, the understandings of what a seascape is, and its ontology, change through human-human and human-environment encounters in different times and places, shaped by the ways in which access to the seascape and its resources have been enforced and altered over time. Thereby, local environmental knowledge about the seascape is never static, and is subjected to constant transformation, as local experiences and understandings collide with external influences, regulations and constraints. Consequently, this has changed understandings of what the sea is for local people. The seascape and its social, political, cultural and ecological dimensions is not understood as an organic whole or 'system', but comprises separate dimensions, entangled in the question of knowing about and managing marine ecosystems.

\section{References}

Agrawal, A. 1995. Dismantling the divide between indigenous and scientific knowledge. Development and Change 26: 413-439.

Balée, W. 1998. Historical ecology: premises and postulates. New York: Columbia University Press. 
Batterbury, S.P.J. 2001. Landscapes of diversity: a local political ecology of livelihood diversification in Southwestern Niger. Cultural Geographies 8(4): 437-464. Researchgate

Bavington, D. 2010. Managed annihilation: an unnatural history of the Newfoundland cod collapse. Vancouver: UBC Press.

Blaikie, P. 1999. A review of political ecology. Zeitschrift für Wirtschaftsgeographie 43(1): 131-147.

Blaikie, P.M. and H.C. Brookfield. 1987. Land degration and society. London and New York: Routledge.

Brown, M. 2015. Seascapes. In M. Brown and B. Humberstone. (eds.) Seascapes shaped by the sea. Farnham: Ashgate. Pp. 13-26.

Bryant, R.L. 1998. Power, knowledge and political ecology in the third world: a review. Progress in Physical Geography 22(1): 79-94.

Bowker, G.C. and S. Leigh Star. 1999. Sorting things out: classification and its consequences. Cambridge, MA: MIT Press.

Connery, C. 1996. Oceanic feeling and regional imaginary. In R. Wilson and W. Dissanayake (eds.) Global/local: cultural production and the transnational imaginary. London: Duke University Press.

Cooney, G. 2003. Introduction: seeing land from the sea. World Archaeology 35(3): 323-28.

Dei, G., J. Sefa, B. L. Hall and D. Goldin Rosenberg. Introduction. In G. Dei, J. Sefa, B.L. Hall and D. Goldin Rosenberg (eds.) Indigenous knowledge in global contexts: multiple readings of our world. Toronto: University of Toronto Press.

Ellen, R. 2002. Déjà vu, all over again. In P. Sillitoe, A. Bicker and J. Pottier (eds.) Participating in development: approaches to indigenous knowledge. London: Routledge.

Environmental Board. 2012. Sangelaiud. Tallinn: Keskkonnaamet. [accessed June 11 2013.] http://register.keskkonnainfo.ee/envreg/main\#HTTPdtUv61MkGpAoqsN0WzAId4ls3WeqvC

Escobar, A. 1998. Whose knowledge, whose nature? Biodiversity, conservation, and the political ecology of social movements. Journal of Political Ecology 5: 53-82.

Gareth J.E. and C.R. Metzo. 2008. Yellowstone embodied: Truman Everts' thirty-seven days of peril. Gender, Place and Culture 15(3): 221-242.

Goldman, M.J. and M.D. Turner. 2011. Introduction. In M.J. Goldman, P. Nadasdy and M.D. Turner (eds.). Knowing nature: conversations at the intersection of political ecology and science studies. Chicago: University of Chicago Press.

Gdansk Convention. 1973. Gdansk convention on fishing and conservation of the living resources in the Baltic $\begin{array}{llllll}\text { Sea and the belts. } & \text { [accessed } & \text { August } & \end{array}$ http://www.jus.uio.no/english/services/library/treaties/06/6-02/fishing-baltic-belts.xml

Gupta, A. 1998. Postcolonial developments: agriculture in the making of modern India. Durham, NC.: Duke University Press.

Harkonen, T., S. Brasseur, J. Teilmann, C. Vincent, R. Dietz, K. Abt and P. Reijnders. 2007. Status of grey seals along mainland Europe from the southwestern Baltic to France. NAMMCO Scientific Publications 6: $57-68$.

Helcom. 1993. Convention on the protection of the marine environment of the Baltic Sea area, 1974 (Helsinki Convention). [accessed January 10 2012.] http://www.helcom.fi/stc/files/Convention/convention1974.pdf

Helcom. 2008. Convention on the protection of the marine environment of the Baltic Sea area, 1992 (Helsinki Convention).

Huff, A. 2014. Weathering the 'long wounded year': livelihoods, nutrition and changing political ecologies in the Mikea forest region, Madagascar. Journal of Political Ecology 21: 83-107.

Hutchings, J.A. 1999. The biological collapse of Newfoundland's northern cod. In D. Newell and R.E. Ommer (eds.). Fishing places, fishing people: traditions and issues in Canadian small-scale fisheries. Toronto: University of Toronto Press.

Ingold, T. 1993. The temporality of the landscape. World Archaeology 25: 152-174. 
Johnsen, J.P., G. Murray and B. Neis. 2009. North Atlantic fisheries in change: from organic associations to cybernetic organizations. MAST 7(2): 55-82.

Jüssi, I., M. Jüssi and R. Müür. 2004. Tegevuskava Läänemere viigerhülge kaitseks Eesti rannikul aastatel 2006 - 2010. [Action plan for protecting ringed seals in Estonia.] Tallinn: Keskkonna Ministeerium.

Jõgisalu, H. 2006. Meri põlõm'te paljas vesi. Kihnu arhipelaag. [Sea is not simply water. Kihnu archipelago.] Tallinn: IIo.

Kalits, V. 2006. Kihnlaste elatusalad. XIX sajandi keskpaigast XX sajandi keskpaigani. [Subsistence of Kihnu people. From XIX century till mid XX century.] Lina küla: Kihnu Kultuuriruum.

Kartau, K. 2013. Pärnu maakonnaga piirneva mereala maakonnaplaneeringu keskkonnamõju strateegilise hindamise programm. [Strategic environmental assessment program for the coastal region in Pärnu County] Tartu: Hendrikson \& Ko.

Kraufelin, P., Z. Pekcnep-Hekim, U. Bergström, A. Florin, A. Lehikoinen, J. Mattila and J. Olsson. 2016. Essential fish habitats (EFH). Conclusions from a workshop on the importance, mapping, monitoring, threats and conservation of coastal EFH in the Baltic Sea. Copenhagen: TemaNord.

Knudsen, S. 2009. Fishers and scientists in modern Turkey. The management of natural resource, knowledge and identity on the eastern Black Sea coast. London: Berghahn Books.

Lambert, D., L. Martins and M. Ogborn. 2006. Currents, visions and voyages: historical geographies of the sea. Journal of Historical Geography 32: 479-493.

Latour, B. 1987. Science in action. Cambridge: Harvard University Press.

Law, J. 2004. After method: mess in social science research. New York: Routledge.

Levidow, L. and C. Marris. 2001. Science and governance in Europe: lessons from the case of agricultural biotechnology. Science and Public Policy 28: 345-360.

Lysenko, T. D. 1948. The science of biology today. London: International Publishers.

Mathews, A. S. 2011. Instituting nature: authority, expertise, and power in Mexican forests. Cambridge: MIT Press.

McNiven, I. 2008. Sentient sea: seascapes as spiritscapes. In B. David and J. Thomas (eds.) Handbook of landscape archeology. Walnut, CA: Left Coast Press.

Neumann, R.P. 2011. Political ecology III: theorizing landscape. Progress in Human Geography 35(6): 843850.

Peil, T. 1999. Islescapes. Estonian small islands and islanders through three centuries. Stockholm: Almqvist and Wiksell.

Plaan, J. 2012. Culture in nature: traditional ecological knowledge and environmentalism in Kihnu. BA dissertation. Estonian Institute of Humanities. Tallinn: Tallinn University.

Ratas, U. 2005. Väikesaared, meie rannikumere aarded. [Small islands, the treasury of our coastal waters.] Eesti Loodus 8: 14-21.

Rattiste, K. and S. Lauri. 2010. Kormoroni levik ja arvukus Eestis. [Cormorant distribution and abundance in Estonia] Tartu: Keskkonnateabe Keskus.

Redford, K., K. Brandon and S. Sanderson. 2005. Holding ground. In N. Haenn, R. Wilk (eds.) The environment in anthropology: a reader in ecology, culture, and sustainable living. New York: New York University Press. Pp. 237-243.

Reeves, R.R. 1998. Distribution, abundance and biology of ringed seals ( NAMMCO Scientific Publications 1: 9-45.

Reuter, T. 2010. Anthropological theory and the alleviation of anthropogenic climate change: understanding the cultural causes of systemic change resistance. World Anthropology Network E-Journal 5: 7-32.

Rose, M. 2002. Landscape and labyrinths. Geoforum 33: 455-467. 
Rubow, C. 2013. Enacting cyclones: the mixed response to climate change in the Cook Islands. In K. Hastrup and M. Skrydstrup (eds.). The social life of climate change models: anticipating nature. London: Routledge. Pp. 57-76.

Rüütel, I. 2013. Naised Kihnu kultuuris. [Women in Kihnu culture.] Tartu: EKM Teaduskirjandus.

Scott, H.V. 2006. Rethinking landscape and colonialism in the context of early Spanish Peru. Environment and Planning D: Society and Space 24: 481-496.

Scott, J. 1998. Seeing like a state: how certain schemes to improve the human condition have failed. New Haven: Yale University Press.

Shiva, V. 1996. Biopiracy: the plunder of nature and knowledge. Boston: South End Press.

Steinberg, P. 1999. Navigating to multiple horizons: toward a geography of ocean-space. Professional Geographer 51(3): 366-375.

Strang, V. 2004. The meaning of water. Oxford: Berg.

Taylor, P.J. 2011. Agency, structuredness, and the production of knowledge within intersecting processes. In M.J. Goldman, P. Nadasdy and M.D. Turner (eds.). Knowing nature: conversations at the intersection of political ecology and science studies. Chicago: University of Chicago Press. Pp. 81-98.

Tilley, C. and K. Cameron-Daum. 2017. An anthropology of landscape. An extraordinary in the ordinary. London: UCL Press.

Torrence, R. 2002. Cultural landscape on Garua Island, Papua New Guinea. Antiquity 76: 766-76.

Turner, M.D. 2011. Introduction. In M.J. Goldman, P. Nadasdy and M.D. Turner (eds.). Knowing nature: conversations at the intersection of political ecology and science studies. Chicago: University of Chicago Press.

Vallner, L., H. Sildvee and T. Ants. 1988. Recent crustal movements in Estonia. Journal of Geodynamics 9: 215-223.

Vetemaa, M., R. Eschbaum, A, Albert, L. Saks, A. Verliin, K. Jürgens, M. Kesler, K. Hubel, R. Hannesson and T. Saat. 2010. Changes in fish stocks in an Estonian estuary: overfishing by cormorants? ICES Journal of Marine Science 67: 1972-1979.

Zimmerer, K. 1999. Overlapping patchworks of mountain agriculture in Peru and Bolivia: toward a regionalglobal landscape model. Human Ecology 27(1): 135-165.

Zent, S. 2012. A genealogy of scientific representations of indigenous knowledge. In S. Heckler (ed.) Landscape, process and power: re-evaluating traditional environmental knowledge. New York: Berghahn Books.

Archival material

EAA.298.2.71. 1866 - 1896. Трехверстная карта Российской Империи. Ряд 6, лист 3. [Map of European Part of Russian Empire].

EAA.2072.3.61aa. 1800. Kihelkonna kihelkonna maade kaart. [Parish Land Map].

Pärnu raj. TSN TK otsus nr.26. Looduslikult kaunite kohtade, parkide, põliste puude, ja rändrahnude ja teiste kaitset väärivate looduslike objektide säilitamine. [About naturally beautiful places, parks, native trees, and boulders and other natural objects, which need protection] 